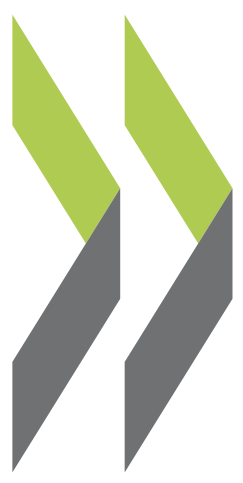

OECD Working Papers on Finance, Insurance and Private Pensions No. 5

The New IAS 19 Exposure Draft

\title{
Clara Severinson
}




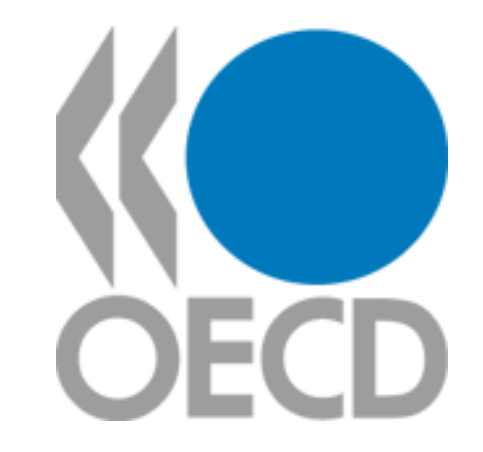

THE NEW IAS 19 EXPOSURE DRAFT

\author{
Clara Severinson
}

September 2010

OECD WORKING PAPER ON FINANCE, INSURANCE AND PRIVATE PENSIONS

No. 5

Financial Affairs Division, Directorate for Financial and Enterprise Affairs

Organisation for Economic Co-operation and Development

2 Rue André Pascal, Paris 75116, France

www.oecd.org/daf/fin/wp 


\section{ABSTRACT/RÉSUMÉ}

\section{The New IAS 19 Exposure Draft}

At the end of April 2010, the International Accounting Standards Board (IASB) published an exposure draft with proposed changes to International Accounting Standard No. 19 (IAS 19). IAS 19 is the current standard for the financial reporting of company pension obligations that stem from defined benefit (DB) and similar plans. It is required for exchange-listed companies in many parts of the world. If enacted, the changes to IAS 19 proposed by the IASB are expected to have a significant impact on company financials on a global basis.

The following paper summarizes the proposed changes as presented in the April 2010 exposure draft and explores some of their implications. This paper does not cover all the changes proposed by the IASB but attempts to focus on some key and controversial issues.

JEL codes: G23, G32, M41, M52

Key words: IASB, IAS 19, defined benefit accounting, pension accounting, market-to-market

\section{Copyright OECD, 2010}

Applications for permission to reproduce or translate all, or part of, this material should be made to: Head of Publications Service, OECD, 2 rue André-Pascal, 75775 Paris Cedex 16, France 


\title{
THE NEW IAS 19 EXPOSURE DRAFT
}

\author{
By Clara Severinson ${ }^{1}$
}

\section{Executive Summary}

At the end of April 2010, the International Accounting Standards Board (IASB) published an exposure draft with proposed changes to International Accounting Standard No. 19 (IAS 19). IAS 19 is the current standard for the financial reporting of company pension obligations that stem from defined benefit (DB) and similar plans. It is required for exchange-listed companies in many parts of the world. If enacted, the changes to IAS 19 proposed by the IASB are expected to have a significant impact on company financials on a global basis.

The proposed IASB changes are significant, although smaller in scope than the proposals made in the previous discussion paper on IAS 19 that was issued by the IASB in March 2008. This paper identifies and discusses some of the key changes proposed in the new exposure draft.

The IASB's proposed changes are expected to go into effect as of 2013. A further review of outstanding issues will be implemented after mid-2011. The proposed changes presented in the exposure draft are an interim step in a long-term process towards an ultimately new method of accounting for companies' pension promises. For the longer-term, a comprehensive overhaul of the standards for pension accounting is planned. With this in mind, it is important to consider whether or not the scope and direction of the current changes are appropriate. There are two important issues that pension policymakers should consider. First, changes in accounting standards are likely to shape how companies design, finance and think about the pension promises they offer to their employees. Second, these accounting changes may have implications for the valuation rules that regulators and supervisors require pension funds to use.

\footnotetext{
${ }^{1}$ Clara Severinson is an Administrator within the same Financial Affairs Division of the OECD. The views expressed are the sole responsibility of the author and do not reflect those of their organisation. The author is solely responsible for any errors.
} 


\section{Introduction}

International Financial Reporting Standards (IFRS) are required or permitted for financial statement reporting in over 100 jurisdictions. The European Union implemented the use of IFRS for exchange-listed companies in 2005. Furthermore, the International Accounting Standards Board (IASB) which authors IFRS has signed a memorandum of understanding with its counterparts in the United States and Japan for convergence work by 2011 and the goal of convergence has been supported by the G20 leaders. ${ }^{2}$

International Accounting Standard No. 19 (IAS 19) is the accounting standard that covers the reporting of employee benefits, and most importantly, employer-sponsored DB pension schemes. IAS 19 is a controversial standard and has been the subject of heated debated, especially since its introduction to the European Union in 2005. At the time of its introduction to the European Union, it was similar to the standard for pension accounting required in the United States at that time. IAS 19 was praised for bringing transparency, standardization and in some cases common sense to accounting for DB pensions. However, it was also criticized for not being sufficiently flexible to deal with the very varied pension systems found in the large new number of countries for which it was now required. In particular, it was too stark in its distinction as to whether pension schemes were to be considered DB or DC and did not address the increasing types of pension schemes that fall somewhere between traditional DB and traditional DC. Furthermore, some criticism was made towards the ability of companies under IAS 19, as well as under its US counterpart, to defer the effect of gains and losses in the pension scheme on the sponsoring company's annual profits and its balance sheet.

The IASB began its re-working of IAS 19 a few years ago and it presented a preliminary discussion paper in March 2008, with a more comprehensive overhaul planned for the long-term. The preliminary discussion paper dealt with a number of key issues listed below. ${ }^{3}$

- The deferred recognition of gains and losses.

- How the changes in a pension scheme's net asset or liability should be recognized in the corporate plan-sponsor's financial statements.

- How to account for pension schemes that are not traditional DB or traditional DC, but that fall somewhere in between.

The March 2008 discussion paper met with a wide public response. The IASB received 150 comment letters, both agreeing and disagreeing with various aspects of the discussion paper. The proposed new accounting treatment of pension schemes that are not traditional DB or DC, but fall somewhere in between, met with critique in many of the comment letters to the effect that the new accounting treatment was overly complex and would not produce consistent results.

In response to the feedback from the discussion paper, at the end of April 2010, the IASB published an exposure draft for a new version of IAS 19. The April 2010 exposure draft is more modest in its proposed amendments than the proposals made in the March 2008 discussion paper. The April 2010 exposure draft covers the following main points:

- The deferred recognition of gains and losses.

\footnotetext{
${ }^{2}$ IASB, "Global Convergence of IFRSs", http://www.iasb.org/Use+around+the+world/Global+convergence/IFRS+global+convergence.htm

${ }^{3}$ A full summary of the March 2008 exposure draft can be found in the Working Party on Private Pensions paper: 'Recent Developments in Pension Accounting'..
} 
- How the changes in a pension scheme's net asset or liability should be recognized in the corporate plan-sponsor's financial statements.

- Revised disclosure requirements, including new disclosure requirements for multi-employer plans and state plans.

- Miscellaneous other items.

Based on the feedback received in the public consultation to the March 2008 discussion paper, the IASB decided not to tackle the issue of hybrid plans in the new exposure draft and they have postponed that discussion at least until mid-2011.

The following paper summarizes the proposed changes as presented in the April 2010 exposure draft and explores some of their implications. This paper does not cover all the changes proposed by the IASB but attempts to focus on some key and controversial issues.

The IASB's full proposal can be found at www.iasb.org in their April 2010 exposure draft titled "Defined Benefit Plans: Proposed Amendments to IAS 19".

\section{Discussion of Proposed Changes}

The scope of the current interim review of IAS 19 covers a number of topics, some of which will mean substantial changes to how companies are currently accounting for their pension promises. In this paper, we have focused on some key proposed changes.

\section{II.1 The Deferred Recognition of Gains and Losses}

Historically, the financial reporting of company pension obligations has allowed companies to defer, or "smooth", the effect of market fluctuations on the pension plan assets and obligations that get reported in the company's balance sheet. This means that the financial position of a company's pension plan at a particular point in time could be reported as significantly better funded or worse funded than would be the case if no smoothing was used and the actual assets and liabilities of the pension plan were reported. The IASB has made clear from the beginning of their review process of IAS 19 that they wish to get rid of this option as they feel that smoothing misstates the true financial position of the plan.

A description of how the smoothing mechanism works in the current version of IAS 19 can be found in the appendix to this paper.

Proponents of the smoothing techniques currently allowed by IAS 19 state that smoothing protects the pension plan which is a very long-term promise by the company to its employees from short-term swings in financial markets. For instance a drop in bond yields of $1 \%$ could in some cases increase a pension plan's DBO on the order of $20 \%-30 \%$. Proponents of smoothing argue that these types of short-term fluctuations have little meaning on the long-term sustainability of the pension plan or the company's ability to pay future promises. Rather, bringing such extremely volatile short-term effects into a company's financial statements on as much as a quarterly basis has the undesired effect of making the decision of offering employees a defined benefit pension plan a decision based on arbitrary and often changing accounting rules, rather than a decision based on the long-term financial sustainability of the pension plan and the company's remuneration policy towards its employees.

Critics of smoothing argue that such techniques hide the true financial status of the pension plan. Pension obligations are like any other company obligation and should be treated as such. Furthermore, 
smoothing produces a distorted picture of reality with complicated and hidden off-balance sheet liabilities. For instance, why should a company be allowed to show a financial gain in the pension plan in a year when assets could have performed poorly and liabilities could have increased more than expected? Alternatively, why should a company have to show a financial loss in a year that assets and liabilities developed better than expected?

The IASB falls into the second of these two camps and they have been consistent in their message that they wish to do away with the option to smooth the effect of actuarial gains and losses. In the new exposure draft, the option to smooth has been eliminated.

\section{II.2 How the changes in a pension scheme's net asset or liability should be recognized in the corporate plan-sponsor's financial statements}

Another of the IASB's proposed change that we discuss is how the changes in plan assets and DBO over the course of a fiscal year should be recognised in a company's financial statements. Currently, companies are allowed to decide how to allocate various aspects of the changes in the pension scheme's assets and liabilities between the operating and financing components of the profit and loss. Under the new exposure draft, companies will not have an option as to how to recognize the annual change in the pension scheme's net asset or liability, but must disaggregate the change into the following three components, and recognize the three components as follows:

- Service Cost: The annual service cost must be recognized in the employment cost component of profit and loss.

- Interest Income or Expense: The annual interest on the defined benefit obligation and the assets must be recognized in the financing component of the profit and loss.

- Remeasurement: Most other changes in a pension scheme's net asset or liability, such as the effect of changes in the discount rate or mortality table, must be classified as "remeasurement" and is recognized through the company's other comprehensive income and will not affect the company's annual profits.

One aspect of this part of the exposure draft that is likely to raise debate is how investment income on the pension scheme's total plan assets will affect a company's annual profits. As mentioned above, the exposure draft proposes that the interest income on the scheme's assets would be recognized as a financing component of the company's profit and loss and it would be measured as the discount rate (which is either a high-quality corporate bond rate or a government bond rate of long duration) multiplied by the pension scheme's total plan assets as of the beginning of the year. Any actual income or investment losses in excess of this amount would be recognised outside of the company's profit and loss statement, through "other comprehensive income". What this means is that regardless of how the pension scheme assets are actually invested, whether in bond's or equities, risk-free assets or in the very riskiest assets, the effect on the company's annual profits would always be determined by the yield on long-term high-quality corporate or government bonds, and not by the actual rate of return of the assets in the pension scheme's portfolio. Companies would not be rewarded in their profit and loss by investing in risky assets (as is arguably the case under the current version of IAS 19), but they would also not be punished in the profit and loss by investment losses. 


\section{II.3 Revised disclosure requirements, including new disclosure requirements for multi-employer plans and state plans}

The exposure draft proposes new requirements for items to be disclosed in companies' annual reports. Firstly, the exposure draft calls for companies to disaggregate the items disclosed in the annual report to "to distinguish plans or groups of plans with materially different risks. For example.... different geographical locations; different characteristics such as flat salary pension plans, final salary pension plans...; different regulatory environments; or, different funding arrangements" ${ }^{4}$ This proposal could significantly expand the amount of space devoted to pensions in annual reports, but it could also show a more nuanced picture than under current practice where disclosed items are typically shown only in the aggregate.

Furthermore, the new exposure draft states that companies would be required give a written summary of how the company's various pension schemes expose the company to various types of risks. The requirements and extent of this written summary on risk exposure is vague.

The new exposure draft also proposes that companies would need to disclose how a change in each significant actuarial assumption would affect the service cost and the defined benefit obligation.

Under the new exposure draft, companies participating in multi-employer plans that are DB in nature would also have more extensive reporting requirements. Often companies with multi-employer plans that are DB in nature account for them as if they were DC as enough information is not available to do full DB accounting. The new exposure draft would require these companies to disclose their expected contributions over the coming five years.

IAS 19 requires companies to account for state plans (or public pension schemes) as if they were multi-employer plans. If State plans are DB in nature, then the new exposure draft would require full multi-employer DB disclosure for these plans, as well, including the requirement to disclose expected contributions to the state plan over the next five years.

\section{II.4 Miscellaneous other items}

The exposure draft proposes some other miscellaneous items which are described briefly below:

- Risk-sharing should be taken into account in the measurement of the defined benefit obligation: If benefits in a DB plan vary according to some type of performance target, for instance if benefits can be reduced if asset levels are too low or if there is conditional indexation, then the measurement of the defined benefit obligation should take this into account as long the measurement is made using "best estimate" assumptions.

- Administration costs and taxes will need to be considered in the defined benefit obligation: Currently practice is mixed as to whether or not companies take administration costs and taxes into account, although often, this would be done only on the asset side. The requirement to take administration costs and taxes into account in the defined benefit obligation is likely to raise liabilities and the annual pension cost recognized in the profit and loss. The pension consulting

\footnotetext{
${ }^{4}$ Paragraph 125B of the April 2010 IAS 19 Exposure Draft.
} 
firm Towers Watson has stated that this requirement may also require a provision for future insurance premiums to national pension guarantee schemes. ${ }^{5}$

- Settlement costs will not affect a company's profit and loss: Settlement costs such as the cost of insurance buy-outs will not affect a company's annual profits. This may provide an incentive for companies to buy out their obligations.

\footnotetext{
${ }^{5}$ Towers Watson, Bulletin: IASB Proposes Changes to IAS 19, http://www.towerswatson.com/assets/pdf/1737/IASB\%20CA-A4-Non-NA_PDF_4-29-10.pdf
} 


\section{APPENDIX: HOW DOES SMOOTHING WORK UNDER THE CURRENT VERSION OF IAS 19}

Under the current version of IAS 19, companies are allowed, but are not required to use smoothing. The companies that do use smoothing must follow a series of relatively complex rules which we describe briefly below.

What happens in practice for companies that use smoothing is that the value of a company's DBO and the pension plan assets are determined at the beginning of each fiscal year. The DBO and the plan assets are then projected to the end of the fiscal year using best-estimate assumptions. These best estimate assumptions would include estimates as to the expected salary increase over the course of the year, the number of people leaving the company, the number of people retiring, etc. It would also include an estimate as to the expected return on plan assets over the course of the fiscal year. At the end of the fiscal year, the company's DBO and plan assets are remeasured. The difference between the expected DBO at the end of the fiscal year and the actual DBO, as well as the difference between the expected plan assets and the actual plan assets at the end of the fiscal year are called "actuarial gains or losses":

\section{DBO Actuarial Loss/(Gain) for the fiscal-year}

\author{
Plan Asset Actuarial Loss/(Gain) \\ for the fiscal-year
}

\author{
$=$ actual DBO at fiscal year-end \\ less \\ expected DBO at fiscal year-end \\ $=$ expected plan assets at fiscal year-end \\ less \\ actual plan assets at fiscal year-end
}

The actuarial gains or losses that arise over the course of a fiscal year due to actual experience differing from beginning-of-year expectations do not affect a company's balance sheet position as of the end of the fiscal year, nor do they affect the company's statement of profit and loss over the course of that fiscal year. Rather, any actuarial gains or losses over the course of the fiscal year would be listed as an "accumulated unrecognised actuarial gain or loss" together with any existing unrecognized actuarial gains and losses from prior fiscal years. 


\section{Accumulated unrecognised actuarial loss/(gain)}

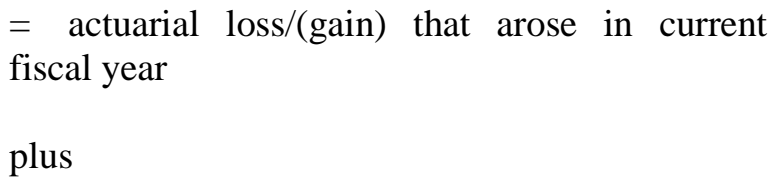

any remaining unrecognised actuarial gains and losses accumulated from prior fiscal years

Once these accumulated unrecognised actuarial gains and losses exceed a pre-defined "corridor" amount ${ }^{6}$, the excess would need to be incrementally recognised in the company's statements of profit and loss over future years. The incremental recognition is done by taking the excess amount and dividing it by the average number of years the company's active employees are expected to remain in service with the company (and accruing benefits within the pension plan). For each of those future years, that amortised excess amount will need to be added to the company's profit and loss statement.

What these complicated rules mean in practice is that swings in the financial markets or adverse demographic experience within the plan do not immediately affect the company's financial statements or its profit and loss. In fact, if an experience loss in one year is offset by an experience gain in a subsequent year, then these gains and losses may never need to be recognized. Ideally, over the life of a pension plan, years with bad financial experience would balance against years with good financial experience to offer smoother financial results. However, this method of smoothing unexpected gains and losses also means that good or bad experience within the pension plan could have an effect on the company's financial statements many, many years into the future.

To illustrate, the following example shows the evolution over 25 years of a fictional company's pension plan balance sheet liability if no smoothing of actuarial gains and losses is applied. This is compared to the balance liability value that could be booked under the current version of IAS 19 if smoothing was used.

\footnotetext{
${ }^{6}$ The total accumulated unrecognized actuarial gain or loss is amortized over the future average working lifetime of the active employees in the plan to the extent that they exceed $10 \%$ of the greater of the pension plans assets or DBO.
} 


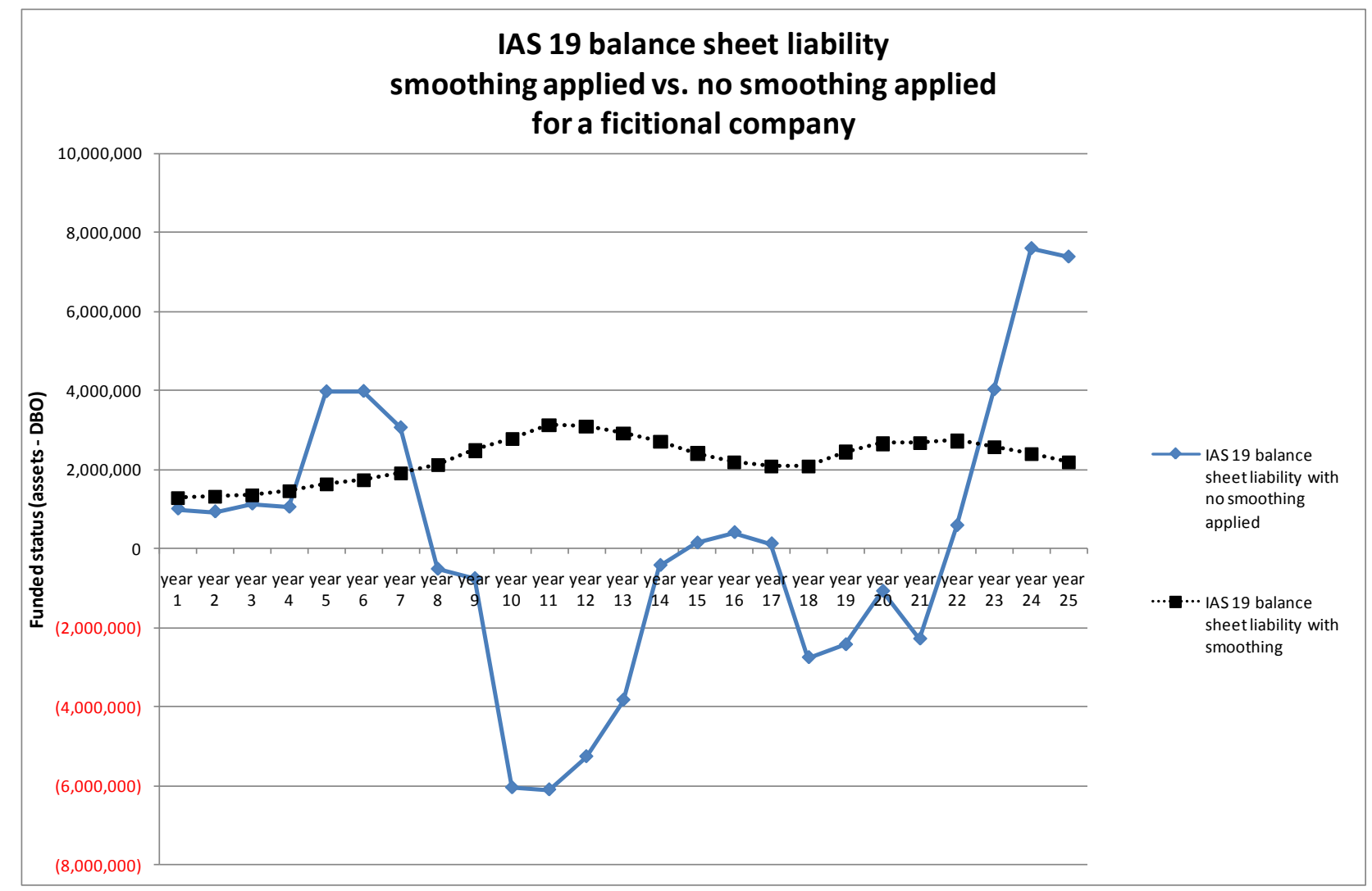

As can be seen by the dotted line representing the fictional company's balance sheet liability for its pension plan with smoothing applied, it is significantly less volatile than the balance sheet liability with no smoothing applied. 